\title{
Environmental Contamination with Hazardous Drugs in Quebec Hospitals
}

\author{
Jean-François Bussières, Cynthia Tanguay, Karine Touzin, Éric Langlois, and Michel Lefebvre
}

\begin{abstract}
Background: Since publication of the US National Institute for Occupational Safety and Health alert on hazardous drugs in 2004, many health care organizations have reviewed their procedures for handling hazardous drugs. Occupational exposure may occur when handling, compounding, or administering a drug considered to be hazardous, at any stage from storage to waste management.
\end{abstract}

Objectives: To describe environmental contamination with cyclophosphamide, ifosfamide, and methotrexate in pharmacy and patient care areas of Quebec hospitals.

Methods: Sixty-eight hospitals were invited to participate. At each hospital, 12 prespecified measurement sites (6 each within pharmacy and patient care areas) were sampled once (midweek, end of day). The samples were analyzed by ultra-performance liquid chromatography tandem mass spectrometry to determine the presence of the 3 drugs. The limits of detection (LODs) were $0.0015 \mathrm{ng} / \mathrm{cm}^{2}$ for cyclophosphamide, $0.0012 \mathrm{ng} / \mathrm{cm}^{2}$ for ifosfamide, and $0.0060 \mathrm{ng} / \mathrm{cm}^{2}$ for methotrexate.

Results: Twenty-five (37\%) of the hospitals agreed to participate. Samples from sites other than the 12 prespecified sites were excluded. Overall, 259 valid samples were collected between April 2008 and January 2010 (147 samples from pharmacy areas in 25 hospitals and 112 samples from patient care areas in 24 hospitals). No hospital was using a closed-system drug transfer device at the time of the study. The median (minimum, maximum) number of sites per hospital with at least 1 positive sample for at least 1 of the 3 hazardous drugs was $6(1,12)$. A total of $135(52 \%)$ samples were positive for cyclophosphamide, 53 (20\%) for ifosfamide, and 7 (3\%) for methotrexate. The median (minimum, maximum) concentration in positive samples was $0.0035 \mathrm{ng} / \mathrm{cm}^{2}$ (below LOD, $28 \mathrm{ng} / \mathrm{cm}^{2}$ ) for cyclophosphamide, below LOD (below LOD, $8.6 \mathrm{ng} / \mathrm{cm}^{2}$ ) for ifosfamide, and below LOD (below LOD, $0.58 \mathrm{ng} / \mathrm{cm}^{2}$ ) for methotrexate.

Conclusions: The levels of environmental contamination with 3 hazardous drugs in this multicentre study were similar to or below those in most published studies. Periodic measurement of surface contamination is necessary to ensure that current practices limit occupational exposure to hazardous drugs.

Key words: occupational exposure, environmental monitoring, cyclophosphamide, ifosfamide, methotrexate, hospital pharmacy service

Can J Hosp Pharm 2012;65(6):428-435

\section{RÉSUMÉ}

Contexte : Depuis la publication en 2004 d'une alerte sur les médicaments dangereux par le National Institute for Occupational Safety and Health des États-Unis, de nombreux organismes de soins de santé ont révisé leurs marches à suivre concernant la manipulation des médicaments dangereux. L'exposition professionnelle peut survenir durant la manipulation, la préparation ou l'administration d'un médicament considéré dangereux, à n'importe quelle étape entre l'entreposage et la gestion des déchets.

Objectifs : Déterminer la contamination environnementale associée à la cyclophosphamide, à l'ifosfamide et au méthotrexate dans les pharmacies et les unités de soins d'hôpitaux québécois.

Méthodes : On a invité 68 hôpitaux à participer à cette étude. Dans chacun des hôpitaux, on a procédé à un échantillonnage dans 12 sites de mesures préétablis ( 6 dans la pharmacie et 6 dans les unités de soins) à une occasion (en mi-semaine, en fin de journée). Les échantillons ont été analysés par chromatographie liquide à très haute performance couplée à la spectrométrie de masse en tandem pour déterminer la présence des trois médicaments. Les limites de détection (LD) étaient de $0,0015 \mathrm{ng} / \mathrm{cm}^{2}$ pour la cyclophosphamide, de $0.0012 \mathrm{ng} / \mathrm{cm}^{2}$ pour l'ifosfamide et de $0,0060 \mathrm{ng} / \mathrm{cm}^{2}$ pour le méthotrexate.

Résultats : Vingt-cinq (37\%) hôpitaux ont accepté de participer à cette étude. Les échantillons prélevés ailleurs que dans les sites préétablis ont été exclus. En tout, 259 échantillons valides ont été recueillis entre avril 2008 et janvier 2010 (147 échantillons dans les pharmacies de 25 hôpitaux et 112 échantillons dans les unités de soins de 24 hôpitaux). Aucun des hôpitaux n'a utilisé un système de transfert fermé durant l'étude. Le nombre médian (minimum, maximum) de sites par hôpital ayant au moins un échantillon positif pour au moins un des trois médicaments dangereux était de $6(1,12)$. Un total de 135 (52\%) échantillons étaient positifs pour la cyclophosphamide, 53 (20\%) pour l'ifosfamide et 7 (3\%) pour le méthotrexate. La concentration médiane (minimum, maximum) de médicament dans les échantillons positifs était de $0,0035 \mathrm{ng} / \mathrm{cm}^{2}$ (sous la $\mathrm{LD}, 28 \mathrm{ng} / \mathrm{cm}^{2}$ ) pour la cyclophosphamide, sous la LD (sous la LD, $8,6 \mathrm{ng} / \mathrm{cm}^{2}$ ) pour l'ifosfamide et sous la LD (sous la LD, $0,58 \mathrm{ng} / \mathrm{cm}^{2}$ ) pour le méthotrexate.

Conclusions : Les niveaux de contamination environnementale par les trois médicaments dangereux dans cette étude multicentrique étaient similaires ou inférieurs à ceux signalés dans la plupart des études publiées. La mesure périodique de la contamination de surface est nécessaire pour s'assurer que les pratiques actuelles limitent l'exposition professionnelle aux médicaments dangereux.

Mots clés : exposition professionnelle, surveillance environnementale, cyclophosphamide, ifosfamide, méthotrexate, service de pharmacie d'hôpital

[Traduction par l'éditeur] 


\section{INTRODUCTION}

Since the publication of the US National Institute for Occupational Safety and Health (NIOSH) alert on hazardous drugs in 2004, ${ }^{1}$ many health care organizations have reviewed their guidelines, policies, and procedures for the safe use of hazardous drugs. ${ }^{2-5}$ Occupational exposure may occur in many ways when handling, compounding, or administering a drug considered to be hazardous, at any stage from storage to waste management. The latest NIOSH list of drugs considered hazardous to health care workers, published in September 2010, contained more than 150 drugs. ${ }^{6}$ Only some of these drugs have been analyzed in the context of environmental contamination in health care centres, including cyclophosphamide, ifosfamide, fluorouracil, methotrexate, and cisplatin. Many hospitals have measured contamination with hazardous drugs on surfaces in pharmacy and patient care areas. Most published studies have provided an overview of the situation at a given point in time, whereas others have reported surface contamination levels before and after implementation of strategies to reduce hazardous drug contamination. Only a few studies have presented results from Canadian hospitals.

In the Hospital Pharmacy in Canada 2009/2010 Report, $99 \%$ of respondents (134/135) reported the use of written policies and procedures for handling hazardous drugs throughout the drug-use process in their respective hospitals. ${ }^{7}$ However, only 33\% (44/135) reported policies and procedures for environmental monitoring of hazardous drugs. ${ }^{7}$ In Quebec, a prevention guide on safe handling of hazardous drugs was published in 2008,5 the result of a collaboration of 10 organizations, led by the Association paritaire pour la santé et la sécurité du travail du secteur des affaires sociales (a joint sector-based association dedicated to promoting occupational health and safety and supporting workers in the health and social service sectors) and including the Pharmacy Practice Research Unit (Unité de recherche en pratique pharmaceutique), Centre hospitalier universitaire Sainte-Justine, and the Institut national de santé publique du Québec (INSPQ). This collaboration contributed to the development of an environmental monitoring program in Quebec, and the prevention guide ${ }^{5}$ recommended that environmental monitoring be performed annually and following major changes to equipment and procedures (e.g., replacement of a biological safety cabinet, introduction of new techniques for preparation or administration of drugs, implementation of new cleaning protocols or new preventive measures).

Following publication of this prevention guide and implementation of local initiatives, Quebec hospitals were invited to participate in a multicentre study to portray the current state of surface contamination with hazardous drugs. The specific aim was to describe environmental contamination with cyclophos- phamide, ifosfamide, and methotrexate in pharmacy and patient care areas of Quebec hospitals.

\section{METHODS}

\section{Study Centres}

Directors of pharmacy departments in hospitals with at least 50 acute care beds were contacted by e-mail between December 1, 2007, and June 30, $2008(n=68)$. Reminders were sent by e-mail, or nonrespondents were contacted by telephone. Each study centre received a copy of the study protocol. Participating hospitals were asked to apply local policies and procedures for compounding, administration, surface cleaning, waste management, and other processes. Each hospital assumed the costs of analyzing their samples.

\section{Sampling Method}

Twelve standardized measurement sites in the pharmacy $(6$ sites) and in patient care areas (6 sites) were prespecified (Table 1 ), according to the likelihood that they might be in contact with hazardous drugs. Photographs of the standardized sampling sites within the Centre hospitalier universitaire Sainte-Justine were sent to each participating hospital, and each hospital was in turn asked to provide photographs of the sites used for sample collection. A trained employee from each participating hospital or a research assistant from the research team collected the samples. For each sample, a standardized surface of about $600 \mathrm{~cm}^{2}(20 \times 30 \mathrm{~cm})$ was sampled with one $6 \mathrm{~cm} \times 8 \mathrm{~cm}$ Wypall X60 wipe (Kimberly Clark Professional, Newton Square, Pennsylvania), moistened with $1 \mathrm{~mL}$ of sampling solution (10\% methanol and $90 \% 5 \mathrm{mmol} / \mathrm{L}$ ammonium acetate). The sites were sampled at the end of a midweek day. The sampling technique was adapted from Larson and others $^{8}$ and was validated by the INSPQ.

\section{Analytical Procedure}

Each sampling wipe was stored between $2^{\circ} \mathrm{C}$ and $8^{\circ} \mathrm{C}$ in a 50-mL polypropylene tube. Before analysis, $10 \mathrm{~mL}$ of extracting solution and appropriate external standards were added to each tube. The tubes were stirred mechanically for $10 \mathrm{~min}$, and an aliquot of the solution was removed for analysis. The specified cytotoxic agents in each extract were quantified by ultra-performance liquid chromatography tandem mass spectrometry (UPLC-MS-MS) technology (Acquity UPLC chromatographic system, coupled with Quattro Premier XE tandem mass spectrometer, Waters, Milford, Massachusetts). Chromatographic analyses were carried out on a $\mathrm{C}_{18}$ Acquity UPLC BEH (bridged ethyl hybrid) column $(2.1 \times 50 \mathrm{~mm}$, $1.7 \mu \mathrm{m}$; Waters) over 2 minutes using mixtures of methanol and $5 \mathrm{mmol} / \mathrm{L}$ ammonium acetate (gradient from 10:90 to 


\section{Table 1. Description of the 12 Standardized Sites to be Sampled in Each Hospital}

Sampling Site Pharmacy

Shipment reception counter

Storage shelf or bin

Front grille inside the hood

Floor in front of the hood

Service hatch or counter for postpreparation validation

Tray used for drug delivery

Patient care areas

Storage shelf or bin

Counter used for priming

and validation

Armrest

Counter in patient's room

Counter in outpatient clinic

Exterior surface of hazardous drug container

$\overline{\mathrm{CP}}=$ cyclophosphamide, $\mathrm{IF}=$ ifosfamide, $\mathrm{MTX}=$ methotrexate. their preparation

\section{Description}

Counter used for receiving shipments and unpacking hazardous drugs

Shelf or bin used for storage of hazardous drugs

Grille located in the front of the main hood (biological safety cabinet) used for compounding hazardous drugs

Floor in front of the main hood used for compounding hazardous drugs Service hatch used to transfer drugs from the compounding room to the post-preparation validation area or counter used by pharmacy personnel for post-preparation validation

Tray or container used to deliver hazardous drugs to patient care areas after

Shelf or bin used for storage of hazardous drugs

Counter used for priming tubing for hazardous drugs and for nurse's final validation of compounded syringes before administration of drugs to patients Armrest (on a chair or elsewhere) where a patient would put his or her arm during administration of a hazardous drug from a peripheral line

Counter (or table) in a patient's room where drugs and related devices are placed during drug administration, in a room where at least one dose of $C P$, $\mathrm{IF}$, or MTX was given in the 12 -h period before sampling

Counter (or table) in an outpatient clinic where drugs and related devices are placed during drug administration, in a location where at least one dose of $\mathrm{CP}$, IF, or MTX was given in the 12-h period before sampling

Exterior surface of syringe or bag containing compounded drug
60:40). Results were expressed in nanograms per millilitre and were also converted to nanograms per square centimetre. Values obtained from the chromatographic analysis were multiplied by 11 (the dilution factor) and divided by 600 (surface area sampled) to obtain the final results reported here. The limit of detection (LOD) was $0.0015 \mathrm{ng} / \mathrm{cm}^{2}(0.080 \mathrm{ng} / \mathrm{mL})$ for cyclophosphamide, $0.0012 \mathrm{ng} / \mathrm{cm}^{2}(0.060 \mathrm{ng} / \mathrm{mL})$ for ifosfamide, and $0.0060 \mathrm{ng} / \mathrm{cm}^{2}(0.33 \mathrm{ng} / \mathrm{mL})$ for methotrexate. The limit of quantification (LOQ) was $0.0050 \mathrm{ng} / \mathrm{cm}^{2}(0.27$ $\mathrm{ng} / \mathrm{mL})$ for cyclophosphamide, $0.0040 \mathrm{ng} / \mathrm{cm}^{2}(0.22 \mathrm{ng} / \mathrm{mL})$ for ifosfamide, and $0.020 \mathrm{ng} / \mathrm{cm}^{2}(1.09 \mathrm{ng} / \mathrm{mL})$ for methotrexate.

\section{Data Analysis}

The proportion of positive samples was calculated. A sample was considered positive if the value was above the LOD. Descriptive statistical analyses were carried out, and data are reported as medians (minimum, maximum). For samples below the LOD, the value of LOD/2 was substituted in calculating the median. ${ }^{9}$ For samples below the LOQ and above the LOD, the value of LOQ/2 was substituted in calculating the median. ${ }^{10}$

\section{RESULTS}

A total of 25 Quebec hospitals participated in the study (37\% response rate), and they collected samples between April 2008 and January 2010. This sample included most of the large teaching hospitals with oncology clinics. None of the participating hospitals was using a closed-system drug-transfer device (CSTD) at the time of the study. One of the 25 hospitals did not provide any samples from patient care areas. In addition, 35 samples from various hospitals were obtained from sites that did not correspond to the standardized sample sites and were excluded from the analysis. Therefore, the total number of samples was 259, consisting of 147 samples from pharmacy areas and 112 samples from patient care areas. Each of the participating hospitals had at least one sample with a positive result for at least 1 of the 3 hazardous drugs evaluated (Figure 1). The median (minimum, maximum) number of sites per centre with at least one positive sample for any drug was $6(1,12)$.

Overall, 52\% (135/259) of the samples were positive for cyclophosphamide, 20\% (53/259) were positive for ifosfamide, and $3 \%(7 / 259)$ were positive for methotrexate (Table 2). For 6 of the 12 sampling sites, more than $50 \%$ of the samples were positive.

Overall, the median (minimum, maximum) concentration of hazardous drugs was $0.0035 \mathrm{ng} / \mathrm{cm}^{2}$ (below LOD, $28 \mathrm{ng} / \mathrm{cm}^{2}$ ) for cyclophosphamide, below LOD (below LOD, $8.6 \mathrm{ng} / \mathrm{cm}^{2}$ ) for ifosfamide, and below LOD (below LOD, $0.58 \mathrm{ng} / \mathrm{cm}^{2}$ ) for methotrexate (Table 3). The 6 sampling sites with the highest proportion of positive (contaminated) samples also presented the highest median cyclophosphamide concentration: front grille inside the hoods (biological safety cabinets), armrests, exterior surface of hazardous drug containers, 


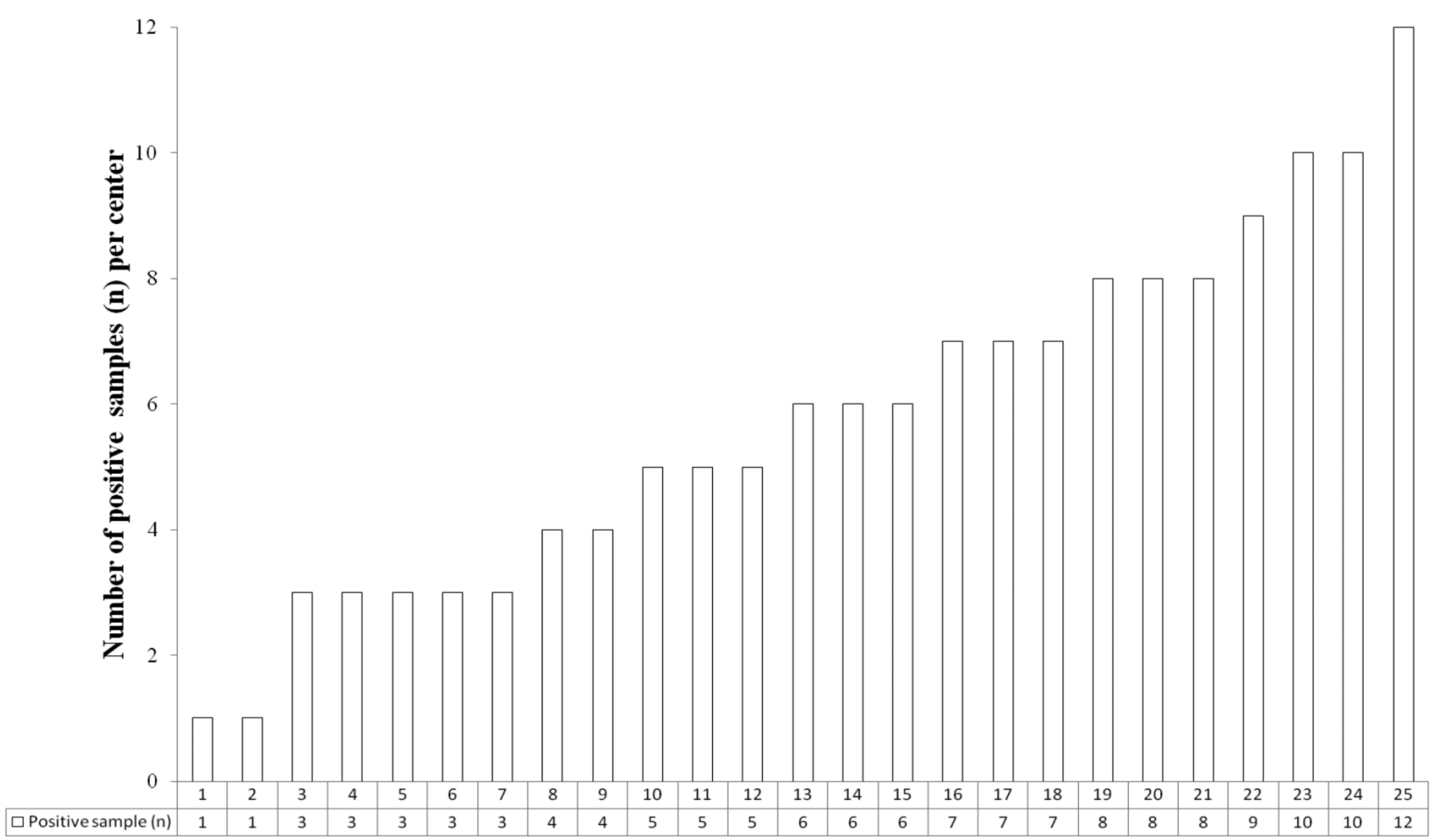

Figure 1. Number of sample sites (in pharmacy and patient care areas) with a positive result for at least one hazardous drug (cyclophosphamide, ifosfamide, or methotrexate). A sample was considered positive if the test result was above the limit of detection (LOD): $0.0015 \mathrm{ng} / \mathrm{cm}^{2}(0.080 \mathrm{ng} / \mathrm{mL})$ for cyclophosphamide, $0.0012 \mathrm{ng} / \mathrm{cm}^{2}(0.060 \mathrm{ng} / \mathrm{mL})$ for ifosfamide, and $0.0060 \mathrm{ng} / \mathrm{cm}^{2}(0.33 \mathrm{ng} / \mathrm{mL})$ for methotrexate. The data are presented in increasing order of number of positive sample sites per centre.

Table 2. Frequency of Positive Samples in Pharmacy and Patient Care Areas*

No. (\%) of Positive Samplest

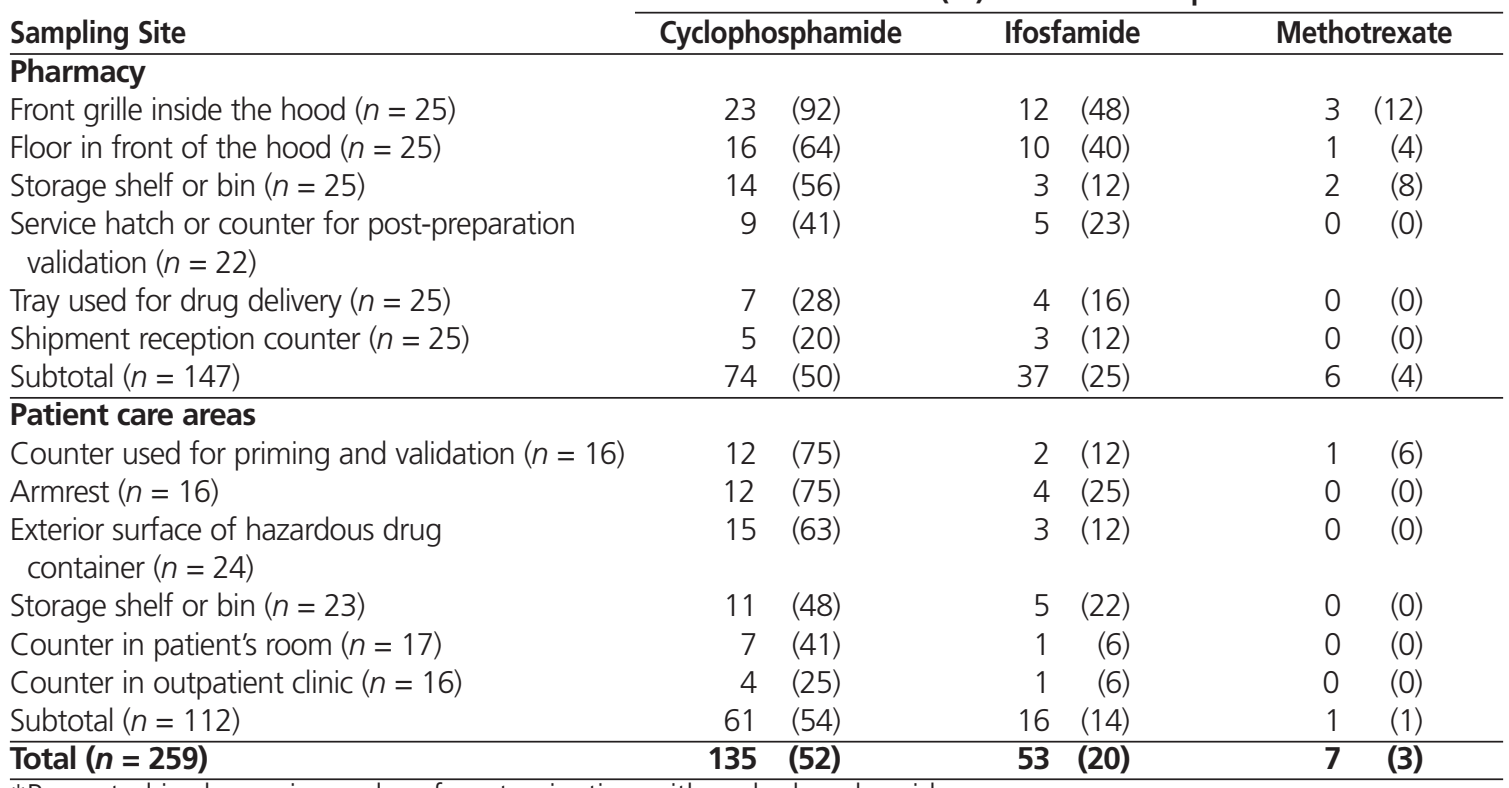

*Presented in decreasing order of contamination with cyclophosphamide.

†A sample was considered positive if contamination was above the limit of detection: $0.0015 \mathrm{ng} / \mathrm{cm}^{2}$ $(0.080 \mathrm{ng} / \mathrm{mL})$ for cyclophosphamide, $0.0012 \mathrm{ng} / \mathrm{cm}^{2}(0.060 \mathrm{ng} / \mathrm{mL})$ for ifosfamide, and $0.0060 \mathrm{ng} / \mathrm{cm}^{2}$ (0.33 ng/mL) for methotrexate. 
Table 3. Concentration of 3 Hazardous Drugs Contaminating Sites in Pharmacy and Patient Care Areas

Concentration (ng/ $\left.\mathrm{cm}^{2}\right)$, Median (Minimum, Maximum)

\begin{tabular}{|c|c|c|c|}
\hline \multirow[b]{2}{*}{$\underline{\text { Sam }}$} & & & \\
\hline & Cyclophosphamide & Ifosfamide & Methotrexate \\
\hline \multicolumn{4}{|l|}{ Pharmacy } \\
\hline Front grille inside the hood $(n=25)$ & $\begin{array}{c}0.090 \\
(<L O D, 3.3)\end{array}$ & $\begin{array}{c}\quad<\mathrm{LOD} \\
(<\mathrm{LOD}, 1.2)\end{array}$ & $\begin{array}{c}<\mathrm{LOD} \\
(<\mathrm{LOD}, 0.58)\end{array}$ \\
\hline Storage shelf or bin $(n=25)$ & $\begin{array}{c}0.0020 \\
(<\mathrm{LOD}, 11)\end{array}$ & $\begin{array}{c}<\mathrm{LOD} \\
(<\mathrm{LOD}, 2.7)\end{array}$ & $\begin{array}{c}<\mathrm{LOD} \\
(<\mathrm{LOD}, 0.060)\end{array}$ \\
\hline Floor in front of the hood $(n=25)$ & $\begin{array}{c}0.010 \\
(<\mathrm{LOD}, 4.2)\end{array}$ & $\begin{array}{c}<\mathrm{LOD} \\
(<\mathrm{LOD}, 8.6)\end{array}$ & $\begin{array}{c}<L O D \\
(<L O D,<L O D)\end{array}$ \\
\hline Tray used for drug delivery $(n=25)$ & $\begin{array}{c}<L O D \\
(<L O D, 0.91)\end{array}$ & $\begin{array}{c}<\mathrm{LOD} \\
(<\mathrm{LOD}, 0.090)\end{array}$ & $\begin{array}{c}<\mathrm{LOD} \\
(<\mathrm{LOD},<\mathrm{LOD})\end{array}$ \\
\hline Shipment reception counter $(n=25)$ & $\begin{array}{c}<\text { LOD } \\
(<L O D, 0.70)\end{array}$ & $\begin{array}{c}<L O D \\
(<L O D, 0.010)\end{array}$ & $\begin{array}{c}<L O D \\
(<L O D,<L O D)\end{array}$ \\
\hline $\begin{array}{l}\text { Service hatch or counter for post-preparation } \\
\text { validation }(n=22)\end{array}$ & $\begin{array}{c}<\mathrm{LOD} \\
(<\mathrm{LOD}, 0.31)\end{array}$ & $\begin{array}{c}<\mathrm{LOD} \\
(<\mathrm{LOD}, 0.20)\end{array}$ & $\begin{array}{c}<\mathrm{LOD} \\
(<\mathrm{LOD},<\mathrm{LOD})\end{array}$ \\
\hline Subtotal $(n=147)$ & $\begin{array}{c}0.0029 \\
(<L O D, 11)\end{array}$ & $\begin{array}{c}<\text { LOD } \\
(<L O D, 11)\end{array}$ & $\begin{array}{c}<L O D \\
(<L O D, 0.58)\end{array}$ \\
\hline \multicolumn{4}{|l|}{ Patient care areas } \\
\hline $\begin{array}{l}\text { Exterior surface of hazardous drug } \\
\text { container }(n=24)\end{array}$ & $\begin{array}{c}0.020 \\
(<\mathrm{LOD}, 28)\end{array}$ & $\begin{array}{c}<\mathrm{LOD} \\
(<\mathrm{LOD}, 0.060)\end{array}$ & $\begin{array}{c}<\mathrm{LOD} \\
(<\mathrm{LOD},<\mathrm{LOD})\end{array}$ \\
\hline Counter used for priming and validation $(n=16)$ & $\begin{array}{c}0.018 \\
(<\mathrm{LOD}, 15)\end{array}$ & $\begin{array}{c}<\mathrm{LOD} \\
(<\mathrm{LOD}, 0.21)\end{array}$ & $\begin{array}{c}<L O D \\
(<L O D, 0.030)\end{array}$ \\
\hline Armrest $(n=16)$ & $\begin{array}{c}0.020 \\
(<L O D, 0.50)\end{array}$ & $\begin{array}{c}<\mathrm{LOD} \\
(<\mathrm{LOD}, 4.2)\end{array}$ & $\begin{array}{c}<L O D \\
(<L O D,<L O D)\end{array}$ \\
\hline Counter in outpatient clinic $(n=16)$ & $\begin{array}{c}<\mathrm{LOD} \\
(<\mathrm{LOD}, 0.40)\end{array}$ & $\begin{array}{c}<\mathrm{LOD} \\
(<\mathrm{LOD}, 0.027)\end{array}$ & $\begin{array}{c}<L O D \\
(<L O D,<L O D)\end{array}$ \\
\hline Storage shelf or bin $(n=23)$ & $\begin{array}{c}<\text { LOD } \\
(<\text { LOD, } 0.16)\end{array}$ & $\begin{array}{c}<\mathrm{LOD} \\
(<\mathrm{LOD}, 0.12)\end{array}$ & $\begin{array}{c}<L O D \\
(<L O D,<L O D)\end{array}$ \\
\hline Counter in patient's room $(n=17)$ & $\begin{array}{c}<\mathrm{LOD} \\
(<\mathrm{LOD}, 0.13)\end{array}$ & $\begin{array}{c}<\mathrm{LOD} \\
(<\mathrm{LOD}, 0.18)\end{array}$ & $\begin{array}{c}<L O D \\
(<L O D,<L O D)\end{array}$ \\
\hline Subtotal $(n=112)$ & $\begin{array}{c}0.0049 \\
(<\text { LOD to } 28)\end{array}$ & $\begin{array}{c}<\mathrm{LOD} \\
(<\mathrm{LOD}, 4.2)\end{array}$ & $\begin{array}{c}<\mathrm{LOD} \\
(<\mathrm{LOD}, 0.027)\end{array}$ \\
\hline Total $(n=259)$ & $\begin{array}{c}0.0035 \\
(<\text { LOD, 28) }\end{array}$ & $\begin{array}{c}<\text { LOD } \\
(<\text { LOD, 8.6) }\end{array}$ & $\begin{array}{c}<\text { LOD } \\
(<\text { LOD, 0.58) }\end{array}$ \\
\hline
\end{tabular}

LOD = limit of detection. The LOD was $0.0015 \mathrm{ng} / \mathrm{cm}^{2}(0.080 \mathrm{ng} / \mathrm{mL})$ for cyclophosphamide, $0.0012 \mathrm{ng} / \mathrm{cm}^{2}$

$(0.060 \mathrm{ng} / \mathrm{mL})$ for ifosfamide, and $0.0060 \mathrm{ng} / \mathrm{cm}^{2}(0.33 \mathrm{ng} / \mathrm{mL})$ for methotrexate.

counters used for priming and validation by nurses, floors in front of the hoods, and storage shelves in the pharmacy. The highest cyclophosphamide concentration $\left(28 \mathrm{ng} / \mathrm{cm}^{2}\right)$ was found on the exterior surface of a drug container.

\section{DISCUSSION}

\section{Proportion of Cyclophosphamide-Positive Samples}

In this multicentre Quebec study, all of the participating hospitals had at least one positive sample for at least one of the hazardous drugs evaluated. The number of sampling sites with a positive result for cyclophosphamide, ifosfamide, or methotrexate varied widely among the 25 centres, ranging from 1 to 12 (out of 12). A total of $52 \%$ of samples had cyclophosphamide contamination, $50 \%$ of those from pharmacy areas and $54 \%$ of those from patient care areas.
Between January 1, 2010, and April 1, 2012, a total of 14 studies with quantitative measures of surface contamination with cyclophosphamide in pharmacy and patient care areas were published. ${ }^{11-24}$ This large group of recently published studies affords a good "snapshot" of current levels of surface contamination in several countries. The studies were conducted in a total of 92 hospitals in 7 countries (28 in Germany, ${ }^{21} 26$ in the United States, ${ }^{1,20,23} 16$ in Italy, ${ }^{14,15,22} 13$ in Japan, ${ }^{11,13,18,19} 6$ in Canada, ${ }^{16} 2$ in Australia, ${ }^{24}$ and 1 in the Czech Republic ${ }^{17}$ ) and represented a total of 1958 samples. Six analytical methods were described, and variations in these methods (e.g., choice of sampling sites, area of sampling surface, LOD, LOQ) limit comparisons among the results.

For 8 of the 14 studies, the hospitals had not implemented a CSTD, and the proportion of cyclophosphamide-positive samples ranged from $14 \%$ to $94 \% .{ }^{11-18}$ For the 6 remaining studies, the hospitals had implemented a CSTD, and for 5 of 
these studies, the proportion of cyclophosphamide-positive samples ranged from $45 \%$ to $82 \% \%^{20-24}$ (the sixth study did not report the proportion of cyclophosphamide-positive samples ${ }^{19}$. In studies in which surface contamination was evaluated before and after implementation of a CSTD, ${ }^{23,24}$ use of a CSTD was shown to be an effective way to reduce surface contamination. Nonetheless, the current results from 25 Quebec hospitals indicate that it is feasible to have a similar (and in some cases, lower) proportion of cyclophosphamidepositive surface samples without a CSTD.

\section{Concentration of Cyclophosphamide on Surfaces}

The median (minimum, maximum) concentration of cyclophosphamide determined in this multicentre study was $0.0029 \mathrm{ng} / \mathrm{cm}^{2}$ (below LOD, $11 \mathrm{ng} / \mathrm{cm}^{2}$ ) in pharmacy areas and $0.0049 \mathrm{ng} / \mathrm{cm}^{2}$ (below LOD, $28 \mathrm{ng} / \mathrm{cm}^{2}$ ) in patient care areas. Three pharmacy sites (front grille inside the hood, floor in front of the hood, and storage shelves) had a median concentration of cyclophosphamide above the LOD. In previously reported studies, these sites frequently had detectable quantities of cyclophosphamide. ${ }^{25}$ For instance, in a study of 22 US hospitals sampled between 2000 and 2005, the median concentration of cyclophosphamide on the airfoils of biological safety cabinets was $3.86 \mathrm{ng} / \mathrm{cm}^{2}\left(<0.02,158 \mathrm{ng} / \mathrm{cm}^{2}\right)$ before implementation of a CSTD and $0.20 \mathrm{ng} / \mathrm{cm}^{2}(0.01,17.15$ $\mathrm{ng} / \mathrm{cm}^{2}$ ) after implementation..$^{23}$ In the study reported here, the median (minimum, maximum) concentration of cyclophosphamide on the front grille inside the hoods was much lower: $0.090 \mathrm{ng} / \mathrm{cm}^{2}$ (below LOD, $3.3 \mathrm{ng} / \mathrm{cm}^{2}$ ).

For 3 sites in patient care areas (exterior surfaces of hazardous drug containers, priming counters, and armrests), the median concentration of cyclophosphamide was above the limit of detection. The highest concentration measured (28 $\left.\mathrm{ng} / \mathrm{cm}^{2}\right)$ was observed on the exterior surface of a cyclophosphamide container that had been delivered to a patient care area. Contamination of the exterior surface of vials is well documented. For instance, Schierl and others ${ }^{26}$ reported that the exterior surface of $85 \%$ of cyclophosphamide vials tested between 2000 and 2008 had a measurable amount of the drug.

\section{Surface Contamination with Cyclophosphamide in Pharmacy and Patient Care Areas}

Similar proportions of positive samples were found in pharmacy and patient care areas in this study, and the median concentration of cyclophosphamide was also similar. Some studies have reported a higher level of contamination in pharmacy areas than in patient care areas. For example, Connor and others ${ }^{20}$ reported that $57 \%$ of samples from pharmacy areas and
$31 \%$ of those from patient care areas were positive for cyclophosphamide. In that study, ${ }^{20}$ the mean concentration of cyclophosphamide ( \pm standard deviation) was $4.0 \pm 13.0 \mathrm{ng} / \mathrm{cm}^{2}$ on pharmacy counters and $0.03 \pm 0.05 \mathrm{ng} / \mathrm{cm}^{2}$ in nursing and patient areas. Higher contamination levels in pharmacy areas are presumably a consequence of the limited surfaces on which manipulations are performed, for example a biological safety cabinet or a validation counter, whereas contamination can occur on most surfaces in patient care areas, for example, counters, armrests, and shelves.

\section{Surface Contamination with Ifosfamide and Methotrexate}

Determining levels of cyclophosphamide was a good method of estimating the level of hazardous drug contamination, given that this drug is used in most health care centres. It also allowed comparison with other studies, given that previous researchers have measured contamination with this drug. Ifosfamide and methotrexate have not been measured as often in previous work. Of the 14 studies on environmental contamination with cyclophosphamide published since 2010, 4 studies also reported ifosfamide values, ${ }^{11,15,20,23}$ and 2 studies also reported methotrexate values. ${ }^{12,16}$

In the 4 previous studies reporting ifosfamide contamination, the proportion of ifosfamide-positive samples was highly variable: $2.1 \%$ in one study, ${ }^{11} 24 \%$ in the second study, ${ }^{20}$ and $53 \%$ in the third ${ }^{23}$ (the fourth study did not report the specific proportion of samples with ifosfamide contamination). In the multicentre study reported here, the overall proportion of ifosfamide-positive samples was midway within this range, at $20 \%$.

Chu and others ${ }^{16}$ reported that $26.1 \%$ of samples from pharmacy areas were positive for methotrexate, and Stover and Achutan $^{12}$ reported that $30.8 \%$ of samples from patient care areas were positive for this drug. In the current multicentre study, the overall proportion of methotrexate-positive samples was much lower, at $3 \%$.

\section{Canadian Studies}

Aside from one study, published in $2011,{ }^{16}$ all Canadian studies on environmental monitoring of surfaces were published before 2010.27-32 The proportion of cyclophosphamide-positive samples (after cleaning) reported by Chu and other ${ }^{16}$ was $57 \%$, with values ranging from below LOD to $1.41 \mathrm{ng} / \mathrm{cm}^{2}$ in pharmacy areas.

\section{Limitations}

This study had several limitations. No data were obtained on the annual drug consumption of the study hospitals, so potential correlations between quantities of hazardous drugs 
handled and levels of surface contamination were not investigated. Moreover, to the best of the authors' knowledge, no study has been able to identify such a correlation, despite attempts to do so. ${ }^{21}$ Another potential limitation of the current study is that more than one research assistant was involved in sampling. Comparison of results from this multicentre study with results from other studies is limited by the high variability of samples sites, sampling techniques, and quantification methods of other published studies. Sites were sampled only once in each hospital, and results for that particular day may not have been representative of usual levels of contamination.

\section{CONCLUSIONS}

A low level of surface contamination with cyclophosphamide was found in the 25 Quebec hospitals in this study. However, $52 \%$ of samples had detectable traces of this drug. Occupational exposure may occur at any step of the drug-use process, from shipment reception to waste management. Following the principle of "as low as reasonably achievable", and assuming that no threshold for safe exposure has been identified, exposure to hazardous drugs should be maintained as low as possible. Periodic environmental monitoring, sustained application of relevant policies and procedures, and the use of personal protective equipment are required to keep contamination at an acceptable (i.e., minimal) level.

\section{References}

1. Preventing occupational exposure to antineoplastic and other hazardous drugs in healthcare settings. Publ No. 2004-165. Atlanta (GA): Department of Health and Human Services (US), Centers for Disease Control and Prevention, National Institute for Occupational Safety and Health; 2004 [cited 2012 Apr 11]. Available from: www.cdc.gov/niosh/docs/2004-165/

2. American Society of Health-System Pharmacists. ASHP guidelines on handling hazardous drugs. Am J Health Syst Pharm 2006;63(12): 1172-1193.

3. International Society of Oncology Pharmacy Practitioners Standards Committee. ISOPP standards of practice. J Oncol Pharm Pract 2007;13 Suppl:1-81.

4. USP $<797>$ guidebook to pharmaceutical compounding - sterile preparations. In: The United States pharmacopeia [28th rev] - The national formulary [23rd ed]. Rockville (MD): United States Pharmacopeial Convention; 2004. p. 2461-2477.

5. Working Committee on the Safe Handling of Hazardous Drugs. Prevention guide: safe handling of hazardous drugs. Montréal (QC): Association paritaire pour la santé et la sécurité au travail du secteur des affaires sociales; 2008 [cited 2012 Apr 11]. Available from: www.asstsas.qc.ca/ publications/publications-specialisees/guides-de-prevention/preventionguide-safe-handling-of-hazardous-drugs.html

6. NIOSH list of antineoplastic drugs and other hazardous drugs in healthcare settings 2010. Publ No. 2010-167. Atlanta (GA): Department of Health and Human Services (US), Centers for Disease Control and Prevention, National Institute for Occupational Safety and Health; 2010 [cited 2012 Apr 11]. Available from: www.cdc.gov/ niosh/docs/2010-167/pdfs/2010-167.pdf

7. Harding J. Chapter C: Drug distribution systems. In: Babich $M$, Bornstein C, Bussières JF, Hall K, Harding J, Lefebvre P, et al, editors. Hospital pharmacy in Canada 2009-2010 report. Eli Lilly; 2010 [cited 2012 Apr 11]. p. 21-35. Available from: www.lillyhospitalsurvey.ca/ hpc2/content/2010_report/chapter_c\%20.pdf
8. Larson RR, Khazaeli MB, Dillon HK. Monitoring method for surface contamination caused by selected antineoplastic agents. Am J Health Syst Pharm 2002;59(3):270-277.

9. Hornung RW, Reed LD. Estimation of average concentration in the presence of nondetectable values. Appl Occup Environ Hyg 1990;5(1):46-51.

10. Directive 2009/90/CE de la Commission du 31 juillet 2009. In: Journal officiel de l'Union européenne. Luxembourg (Belgium): European Union, Publications Office; 2009 [cited 2012 Apr 11]. Available from: http://eurlex.europa.eu/LexUriServ/LexUriServ.do?uri=OJ:L:2009:201:0 036:0038:FR:PDF. See "Article 5: Calcul des valeurs moyennes".

11. Maeda S, Miyawaki K, Matsumoto S, Oishi M, Miwa Y, Kurokawa N. Evaluation of environmental contaminations and occupational exposures involved in preparation of chemotherapeutic drugs. Yakugaku Zasshi 2010;130(6):903-910.

12. Stover D, Achutan C. Occupational exposures to antineoplastic drugs in an oncology-hematology department. J Occup Environ Hyg 2011; 8(1):D1-D6.

13. Sugiura S, Nakanishi H, Asano M, Hashida T, Tanimura M, Hama T, et al. Multicenter study for environmental and biological monitoring of occupational exposure to cyclophosphamide in Japan. J Oncol Pharm Pract 2011;17(1):20-28.

14. Sottani C, Porro B, Comelli M, Imbriani M, Minoia C. An analysis to study trends in occupational exposure to antineoplastic drugs among health care workers. J Chromatogr B Analyt Technol Biomed Life Sci 2010;878(27):2593-2605.

15. Sottani C, Porro B, Imbriani M, Minoia C. Occupational exposure to antineoplastic drugs in four Italian health care settings. Toxicol Lett 2012;213(1):107-115.

16. Chu WC, Hon CY, Danyluk Q, Chua PP, Astrakianakis G. Pilot assessment of the antineoplastic drug contamination levels in British Columbian hospitals pre- and post-cleaning. J Oncol Pharm Pract 2012;18(1):46-51. Epub 2011 Jul 7.

17. Odraska P, Dolezalova L, Piler P, Oravec M, Blaha L. Utilization of the solid sorbent media in monitoring of airborne cyclophosphamide concentrations and the implications for occupational hygiene. J Environ Monit 2011;13(5):1480-1487.

18. Sugiura S, Asano M, Kinoshita K, Tanimura M, Nabeshima T. Risks to health professionals from hazardous drugs in Japan: a pilot study of environmental and biological monitoring of occupational exposure to cyclophosphamide. J Oncol Pharm Pract 2011;17(1):14-19.

19. Yoshida J, Koda S, Nishida S, Yoshida T, Miyajima K, Kumagai S. Association between occupational exposure levels of antineoplastic drugs and work environment in five hospitals in Japan. J Oncol Pharm Pract 2011;17(1):29-38.

20. Connor TH, DeBord DG, Pretty JR, Oliver MS, Roth TS, Lees PSJ, et al. Evaluation of antineoplastic drug exposure of health care workers at three university-based US cancer centers. J Occup Environ Med 2010;52(10):1019-1027.

21. Kopp B, Schierl R, Nowak D. Evaluation of working practices and surface contamination with antineoplastic drugs in outpatient oncology health care settings. Int Arch Occup Environ Health 2012 Feb 5. Epub ahead of print.

22. Turci R, Minoia C, Sottani C, Coghi R, Severi P, Castriotta C, et al. Occupational exposure to antineoplastic drugs in seven Italian hospitals: the effect of quality assurance and adherence to guidelines. J Oncol Pharm Pract 2011;17(4):320-332.

23. Sessink PJM, Connor TH, Jorgenson JA, Tyler TG. Reduction in surface contamination with antineoplastic drugs in 22 hospital pharmacies in the 
US following implementation of a closed-system drug transfer device. $J$ Oncol Pharm Pract 2011;17(1):39-48.

24. Siderov J, Kirsa S, McLauchlan R. Reducing workplace cytotoxic surface contamination using a closed-system drug transfer device. J Oncol Pharm Pract 2010;16(1):19-25.

25. Tanguay C, Langlois E, Lefebvre M, Bussières JF. Surveillance environnementale et médicaments dangereux mise à jour 2011. Bull Inform Toxicol 2011 Oct 11 [cited 2012 Apr 11]. Available from: http://portails.inspq.qc.ca/toxicologieclinique/surveillanceenvironnementale-des-medicaments-dangereux-mise-a-jour-2011.aspx

26. Schierl R, Herwig A, Pfaller A, Groebmair S, Fischer E. Surface contamination of antineoplastic drug vials: comparison of unprotected and protected vials. Am J Health Syst Pharm 2010;67(6):428-429.

27. Bigelow S, Schulz H, Dobish R, Chambers CR. Antineoplastic agent workplace contamination study: the Alberta Cancer Board Pharmacy perspective phase III. J Oncol Pharm Pract 2009;15(3):157-160.

28. Touzin K, Bussières JF, Langlois E, Lefebvre M. Evaluation of surface contamination in a hospital hematology-oncology pharmacy. J Oncol Pharm Pract 2009;15(1):53-61.

29. Bussières JF, Théorêt Y, Prot-Labarthe S, Larocque D. Program to monitor surface contamination by methotrexate in a hematology-oncology satellite pharmacy. Am J Health Syst Pharm 2007;64(5):531-535.

30. Bussières JF, Sessink PJ, Prot-Labarthe S, Larocque D. Évaluation de l'exposition professionnelle aux antinéoplasiques dans une unite de pharmacie hospitalière. Arch Mal Prof 2006;67(6):880-888.

31. Schulz H, Bigelow S, Dobish R, Chambers CR. Antineoplastic agent workplace contamination study: the Alberta Cancer Board Pharmacy perspective. J Oncol Pharm Pract 2005;11(3):101-109.

32. Connor TH, Anderson RW, Sessink PJ, Broadfield L, Power LA. Surface contamination with antineoplastic agents in six cancer treatment centers in Canada and the United States. Am J Health Syst Pharm 1999;56(14):1427-1432.
Jean-François Bussières, BPharm, MSc, MBA, FCSHP, is Head of the Pharmacy Department and Pharmacy Practice Research Unit, Centre hospitalier universitaire Sainte-Justine, and Professor in the Faculty of Pharmacy, Université de Montréal, Montréal, Quebec.

Cynthia Tanguay, BSc, MSc, is a Research Assistant with the Pharmacy Practice Research Unit, Centre hospitalier universitaire Sainte-Justine, Montréal, Quebec.

Karine Touzin, BSc, MSc, is a Research Assistant with the Pharmacy Practice Research Unit, Centre hospitalier universitaire Sainte-Justine, Montréal, Quebec.

Éric Langlois, MSc, is a Chemist with the Centre de toxicologie du Québec, Institut national de santé publique du Québec, Québec, Quebec.

Michel Lefebvre, MSc, is a Chemist with the Centre de toxicologie du Québec, Institut national de santé publique du Québec, Québec, Quebec.

\section{Address correspondence to:}

Jean-François Bussières

Pharmacy Department

Centre hospitalier universitaire Sainte-Justine

3175, chemin de la Côte Sainte-Catherine

Montréal QC H3T 1C5

e-mail: jf.bussieres@ssss.gouv.qc.ca

\section{Acknowledgements}

The authors would like to thank Angélique Métra, Ing, CRHA, consultant with the Association paritaire pour la santé et la sécurité du travail du secteur affaires sociales, Montréal, Quebec, and Delphine Merger, Research Assistant, Pharmacy Practice Research Unit, Centre hospitalier universitaire Sainte-Justine, Montréal, Quebec, and pharmacy intern, Faculté de pharmacie, Université de Nancy, Lorraine, France.

\section{ON THE FRONT COVER}

\section{Whirlpool Point, Kootenay Plains, Alberta}

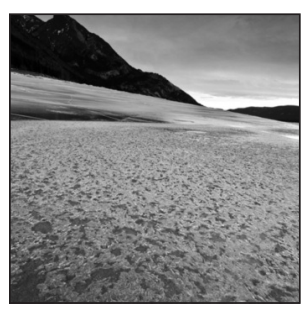

The waters of Abraham Lake, an artificial reservoir, drain into the North Saskatchewan River, with the levels being controlled by the Bighorn Dam. As the water levels drop over the winter months, the ice collapses, forming shoreline "icebergs" and huge plates of ice that slope down and away from the surrounding mountains. This photograph was taken at sunrise on Valentine's Day, 2010. The day before had been unseasonably warm, allowing the surface ice to thaw a little. The ice had frozen again during the night, and walking across the resulting ice flakes was like walking on corn flakes made of glass. To take this photograph, Jim Dobie (husband of CSHP member Terri Schindel) used a Canon EOS 5D Mark II camera and a Canon 17-mm TSE lens (f/10, shutter speed 2.0 seconds). The RAW image capture was edited with Adobe Lightroom software, with final edits completed in Adobe Photoshop.

The CJHP would be pleased to consider photographs featuring Canadian scenery taken by CSHP members for use on the front cover of the journal. If you would like to submit a photograph, please send an electronic copy (minimum resolution $300 \mathrm{dpi}$ ) to Colleen Drake at cdrake@cshp.ca. 